Jurnal Bisnis dan Manajemen, Volume 22, No. 2, September 2022, p. 147-161

\title{
THE ROLE OF COMPETITIVE ADVANTAGE TO ENHANCE MARKETING PERFORMANCE: A STUDY ON INDONESIAN MSME BUSINESS COMMUNITY
}

\author{
Dorojatun Prihandono', Angga Pandu Wijaya ${ }^{2}$, Aufaa Afiffah Ainii ${ }^{3}$ \\ 1,2,3 Universitas Negeri Semarang, Indonesia
}

\begin{abstract}
The rapid development of global business requires MSMEs to understand what the market needs. The research deals with the impact of competitive advantage as a pertinent variable in enhancing marketing performance in Indonesian MSMEs businesses. In this study, continuous competitive advantage is a focal idea to keep up with today's disruptive market in the digital era. This study examines how market orientation and entrepreneurial orientation influence marketing performance through competitive advantage in MSMEs businesses in Indonesia. The study uses path analysis and data collection obtained by using a sample from the MSME business community. The results show that market orientation and entrepreneurial orientation have a positive and significant effect on marketing performance, and competitive advantage can mediate it. For MSME, it is hoped that it can increase response to competitors' actions, open-mindedness, be proactive in responding to market opportunities, and differentiation strategies.
\end{abstract}

Keywords: Marketing Performance, Competitive Advantage, Market Orientation, Entrepreneurial Orientation

\section{PERAN KEUNGGULAN KOMPETITIF UNTUK MENINGKATKAN KINERJA: STUDI PADA KOMUNITAS UMKM DI INDONESIA}

\begin{abstract}
ABSTRAK
Pesatnya perkembangan bisnis global menuntut UMKM untuk memahami apa yang dibutuhkan pasar. Penelitian ini membahas dampak keunggulan bersaing sebagai variabel terkait dalam meningkatkan kinerja pemasaran pada bisnis UMKM di Indonesia. Dalam penelitian ini keunggulan kompetitif yang berkelanjutan adalah ide utama untuk mengikuti pasar yang mengganggu saat ini di era digital. Penelitian ini bertujuan untuk mengkaji bagaimana pengaruh orientasi pasar dan orientasi kewirausahaan terhadap kinerja pemasaran melalui keunggulan bersaing pada usaha UMKM di Indonesia. Penelitian ini menggunakan analisis jalur dan pengumpulan data yang diperoleh dengan menggunakan sampel dari komunitas bisnis UMKM. Hasil penelitian menunjukkan bahwa orientasi pasar dan orientasi kewirausahaan berpengaruh positif dan signifikan terhadap kinerja pemasaran dan keunggulan bersaing dapat memediasinya. Bagi UMKM diharapkan dapat meningkatkan respon terhadap tindakan pesaing, keterbukaan pikiran, proaktif dalam merespon peluang pasar, dan strategi diferensiasi..
\end{abstract}

Kata-kata Kunci: Kinerja Pemasaran, Keunggulan Kompetitif, Orientasi Pasar, Orientasi Kewirausahaan

Korespondensi: Dorojatun Prihandono, S.E., M.M., Ph.D. Jurusan Manajemen, Fakultas Ekonomi, Universitas Negeri Semarang. Sekaran, Gunungpati, Kota Semarang, 50229. Email: dprihandono@ mail.unnes.ac.id. 
Jurnal Bisnis dan Manajemen, Volume 22, No. 2, September 2022, p. 147-161

\section{INTRODUCTION}

Micro, Small and Medium Enterprises (MSMEs) are the largest segment for national business players and play important role in Indonesian economy. MSMEs have a very large number of businesses that involve varied business groups in Indonesia, and it provides a huge amount of contribution to labour market (Cuevas-Vargas et al., 2016). Limited capital, marketing difficulty, lack of human skills, raw materials procurement, and technology are common obstacles faced by MSMEs (Girish et al., 2015). There are more and more competitors in this sector, and MSME marketers are required to be able to quickly recognize and understand what is happening in the market and know what the market needs.

MSMEs are obliged to identify what customers need are be able to determine strategies in facing competition to minimize weaknesses and optimized the strengths owned by MSME marketers (Pizarro, 2016). In the current scope, in practice, it is necessary to know that change and adaptability, and competitiveness is essential for the survival of any organization. The existence of business pressure from strong competitors indirectly affects the marketing performance experienced by these MSME marketers. So by improving marketing performance in MSMEs is one strategic step in doing business and is very necessary in order to be a good business and be able to compete with competitors. Marketing performance can be influenced by factors that are often used to measure the impact of the strategy applied to the company. The company's strategy is always directed at producing excellent marketing performance and also feasible finance (Liang \& Gao, 2020). Marketing performance can be influenced by several variables, one of which is market orientation. Market-oriented companies can compete with other companies and of course, can take advantage of these changes which will result in superior performance compared to other companies that are not market-oriented. Market orientation can improve marketing performance by meeting customer needs and desires and providing products or services that customers want and need (Propheto et al., 2020). The character of an entrepreneur will affect business performance. Theoretically, by having a creative, innovative nature with an unyielding nature, dare to take risks, and having an optimistic attitude are the main characteristics of entrepreneurs and all of those need to be embedded in every MSMEs business individuals.

Competitive advantage in MSMEs businesses can be created by providing means to outperform their competitors and focused on external factors. Therefore, the company must be able to foresee changes and customers' needs. Competitive advantage will affect marketing performance so that the companies can compete in competitive markets (Yasa et al., 2020). This study responses to develop models in examining determinants that have influences in marketing performance in MSMEs in Indonesia. Moreover, 
Jurnal Bisnis dan Manajemen, Volume 22, No. 2, September 2022, p. 147-161

the study provides empirical evidence on how market orientation, entrepreneurial orientation, and competitive advantage influence market performance and also the role of competitive advantage mediates the relationships between those determinants and market performance in the MSMEs sector. This model will be a groundwork for both academics and practices to enhance the determinants that can support MSMEs businesses to enhance their marketing performance. Although several studies have been conducted using the determinants, this study provides a clearer picture for both academic and practice stakeholders in understanding the current condition of Indonesian MSMEs. This research is important due to the need to enhance the Indonesia MSMEs market performance in this pandemic era to survive throughout this disruptive economic condition. The MSME condition in Indonesia is similar to each other, therefore an MSME represents entire Indonesian MSME. The sample of this study is the MSMEs businesses based in Banten which portrays the developed region in Indonesia

\section{LITERATURE REVIEW}

Market orientation is a strategic orientation characterized by a series of behaviours and activities related to the strong customer focus of MSMEs, coordinated marketing throughout the organization, and profitability. Meanwhile, market orientation is the company's ability to study or understand market conditions of customers (understand customer wants and needs) and its competitors (understand their strengths and weaknesses) to maintain their customers or to obtain superior value from customers to improve marketing performance (Heng et al., 2020; Marolt et al., 2020). Furthermore, Manambing (2018) in his study emphasized that company's culture create market orientation to enhance marketing performance, therefore if the businesses have a certain pattern of culture in understanding market where its operates, market orientation embedded in the company. Based in the previous studies, market orientation has a significant effect on marketing performance (Na et al., 2019), the competence of marketing knowledge can improve marketing performance and can be developed the first hypotheses as follows.

H1: Market orientation has a positive effect on marketing performance.

Entrepreneurial orientation is a strategymaking process that provides the basis for organizations for entrepreneurial decisions and actions intending to create a competitive advantage, furthermore entrepreneurial orientation also a process of identifying, developing, and bringing vision into life (Wach et al., 2018). The vision can be in form of innovative way and better way of doing things in a company. The result of this process is creation of new ventures that has resistance in coping with recent economic condition (Liang \& Gao, 2020). 
Jurnal Bisnis dan Manajemen, Volume 22, No. 2, September 2022, p. 147-161

Researchers seem to agree conceptually that entrepreneurial orientation should contribute to company's superior performance (ManzanoGarcía \& Ayala-Calvo, 2020). Empirical evidence also shows positive influence of entrepreneurial orientation on various performance measures such as financial performance, company growth, and overall business performance. Previous studies have also stated that MSMEs showing a high level of entrepreneurial orientation will achieve superior performance compared to those with low entrepreneurial orientation (Covin \& Wales, 2019). Based on the previous studies, the second hypothesis of this study is:

$\mathrm{H} 2$ : Entrepreneurial orientation has positive effect on marketing performance.

Competitive advantage is the heart of company performance that grows from the value or benefits that the company creates for its customers (Hacioglu \& Gök, 2013). Competitive advantage is a company's unique market position that allows it to obtain returns above the average for the industry. Competitive advantage is defined as a company benefit strategy that collaborates to create a more effective competitive advantage in the market. Companies can easily realize competitive advantages in the market if the company can choose an accurate strategy in analyzing the market so that it can maintain its market share and take over market share from competitors. Competitive advantage has a positive and significant effect on marketing performance (Reimann et al., 2021). Competitive advantage sits as an intervening variable, marketing performance becomes the dependent variable and market orientation, and entrepreneurial orientation becomes the independent variable. Based on previous studies, this research is able to develop the third hypothesis as follow:

H3: Competitive advantage has a positive effect on marketing performance.

Musrifah and Murwatiningsih (2017: 503) state that market orientation has a positive and significant effect on marketing performance through competitive advantage. In line with previous study, Setyawati (2013:30) states that market orientation affects performance through competitive advantage. The ability to adapt to an MSME will affect the ability to survive and overall performance of a company, particularly the ability to become a market-oriented business by paying attention to opportunities that arise in order to fulfill consumer needs and demands. This market orientation will guide the business to pay more attention to consumer needs by means of digitalization (Joensuu-Salo, 2018). SMEs that have competitive advantages are open for better marketing performance market-orientation will lead MSMEs for better marketing performance compared to their competitors. Marketing capabilities in MSMEs play an essential role in boosting sales competence in recognizing 
Jurnal Bisnis dan Manajemen, Volume 22, No. 2, September 2022, p. 147-161

consumer demand and conduct innovation (Kamboj \& Rahman 2017). The ability to innovate can have a wider influence. Innovation is one indicator of competitive advantage that can promote marketing performance capabilities (Dabrowski et al., 2019). To conclude, competitive advantage driven by market orientation will affect marketing performance, and the fourth hypothesis of this study is:

H4: Competitive advantage mediates the effect of market orientation on marketing performance.

The relationship between entrepreneurial orientation and marketing performance in business entities, including MSMEs involves a particular determinant, which is competitive advantage. Setyawati (2013:30) shows that competitive advantage mediates the relationship between entrepreneurial orientation and marketing performance. Furthermore, in their study, Mahmood and Hanafi (2013: 36) emphasize that competitive advantage also mediates entrepreneurial orientation on its relation with company performance. Competitive advantage can be achieved by various factors, one of which influences is the ability to improve service quality based on entrepreneurial orientation. Entrepreneurial orientation emphasizes aspects that can empower others and achieve profits. As soon as MSMEs can improve marketing performance, various resources can be utilized, such as sales and promotions, by empowering their resources. In improving marketing performance, competitive advantage is one factor that strengthens the entrepreneurial orientation in improving marketing performance (Lekmat et al., 2018). Entrepreneurial orientation has been proven to influence marketing performance. In addition, Jin \& Cho (2018) have recognized that competitive advantage can intervene entrepreneurial orientation towards marketing performance. Thus, the fifth hypothesis is as follows.

H5: Competitive advantage mediates the effect of entrepreneurial orientation on marketing performance.

\section{METHODS}

The population of the study is 811 MSMEs. In order to meet the statistics sample determination requirement, the study employs the Slovin formula using an $8 \%$ error tolerance (Hair et al., 2014). Based on the formula this study obtain 89 samples and rounded up to 100 respondents. The dependent variable in this study is the marketing performance while the independent variables in this study are the market orientation and entrepreneurial orientation. The intervening variable in this study is the competitive advantage that connects market orientation and entrepreneurial orientation to marketing performance. The data collection method is a questionnaire that is referred to MSMEs using a Likert scale. The Likert scale is applied to measure the attitudes, opinions, and perceptions of a person and a group of people about social 
Jurnal Bisnis dan Manajemen, Volume 22, No. 2, September 2022, p. 147-161

phenomena, which in this study are referred to as research variables. The sampe of this study is the MSMEs businesses in Tangerang, West Java, Indonesia

\section{RESULTS AND DISCUSSION}

\section{Validity and Reliability Test}

This study tested the validity by using 30 samples, the df amount is $30-2=28$. The alpha used for this test was $5 \%$, the $\mathrm{r}$ table value was 0.361 . Based on the validity test results of all the research instruments as many as 45 statement items were declared valid. Therefore, 45 statement items will be used as a measuring tool for this research. The reliability test in this study used the Cronbach's Alpha method. If the coefficient obtained is > 0.70 (Hair et al., 2014), the research instrument is reliable.

\section{Table 1. Reliability Test Result}

\begin{tabular}{|c|c|c|c|}
\hline No & Variable & $\begin{array}{l}\text { Cronchbach's } \\
\text { Alpha Value }\end{array}$ & Results \\
\hline 1 & $\begin{array}{l}\text { Market } \\
\text { Orientation }\end{array}$ & 0,799 & Reliable \\
\hline 2 & $\begin{array}{l}\text { Entrepreneurial } \\
\text { Orientation }\end{array}$ & 0,887 & Reliable \\
\hline 3 & $\begin{array}{l}\text { Marketing } \\
\text { Performance }\end{array}$ & 0,905 & Reliable \\
\hline 4 & $\begin{array}{l}\text { Competitive } \\
\text { Advantage }\end{array}$ & 0,894 & Reliable \\
\hline
\end{tabular}

In the partial test, this study applied this test to determine the effect of each independent variable on the dependent variable. The partial test applied a significance level of $5 \%$. This test requires that if the probability or the $\mathrm{t}$ value $<5 \%$, the hypothesis is accepted (significant regression coefficient), and vice versa.
Table 2. Regression Test Result Model 1

\begin{tabular}{lccc}
\hline \multicolumn{1}{c}{ Variable } & $\begin{array}{c}\text { Std } \\
\text { Error }\end{array}$ & t & Sig \\
& 0.086 & 2.685 & 0.045 \\
Market Orientation & 0.081 & 3.115 & 0.002 \\
Entrepreneurial & & & \\
Orientation & & & \\
\hline
\end{tabular}

To determine the variance of regression model 1 , the following formula is used:

$\mathrm{e}_{1}=\sqrt{ } 1-0,570$
$\mathrm{e}_{1}=0,655$

Referring to the two tables above, the regression structure equation for model 1 can be determined as follows:

$Z=\beta_{1} X_{1}+\beta_{2} X_{2}+\beta_{3} X_{3}+e_{1}$

$Z=0,170 X_{1}+0,531 X_{2}+0,235 X_{3}+0.655$

The Influence of Market Orientation, Entrepreneurship Orientation and Competitive Advantage on Marketing Performance (Model 2). To determine the variance of the regression model 2 , the following formula is used:

$\mathrm{e}_{2}=\sqrt{ } 1-0,871$

$\mathrm{e}_{2}=0,359$

Referring to the two tables above, the regression structure equation for model 2 can be determined as follows:

$Y=\beta_{4} X_{1}+\beta_{5} X_{2}+\beta_{6} X_{3}+\beta_{7} X_{3}+e_{2}$
$Y=0,095 X_{1}+0,193 X_{2}+0,125 X_{3}+0,656 Z+$ 0.359

\section{The Influence Market Orientation on Marketing Performance}

The results of the test in Table 2 show market orientation effect on marketing performance; the tvalue is 2.685 and significant value of $0.045(<$ 0.05), indicate market orientation influence 
Jurnal Bisnis dan Manajemen, Volume 22, No. 2, September 2022, p. 147-161

marketing performance positive and significantly; therefore, hypothesis 1 is accepted.

\section{The Influence of Entrepreneurial Orientation on} Marketing Performance

Table 2 shows examination results of entrepreneurial orientation on marketing performance. The result shows t-value is 3.115 , and the significant value is $0.002(<0.05)$, which means that market orientation affects marketing performance; therefore, hypothesis 2 is accepted.

The Influence of competitive advantage on marketing performance

The examination results in Table 3 show the effect of competitive advantage on marketing performance is indicated by a t-value is 11.696 and a significant value of 0.000 . The result shows that competitive advantage affects marketing performance positively; therefore, hypothesis 3, competitive advantage affects marketing performance, is accepted.

Table 3. Regression Test Result Model 2

\begin{tabular}{llll}
\hline Variable & $\begin{array}{l}\text { Std } \\
\text { Error }\end{array}$ & t & Sig \\
\hline Market Orientation & 0.053 & 2.085 & 0.04 \\
$\begin{array}{l}\text { Entrepreneurial } \\
\text { Orientation }\end{array}$ & 0.052 & 2.884 & 0.05 \\
Competitive Advantage & 0.062 & 11.696 & 0.00 \\
\hline
\end{tabular}

\section{The influence of market orientation on marketing} performance through competitive advantage

The indirect effect of market orientation on marketing performance through competitive advantage can be determined by multiplying the market orientation and competitive advantage path coefficient, with the following result $0.170 \times 0.656$ $=0.111$.
The total effect of the path coefficient obtains from adding up the direct effect (point a) and the indirect effect (point b) $0.095+(0.170 \times 0.656)=0.206$.

Based on the calculation, the path coefficient's total effect is 0.206 , while the path coefficient of direct influence of market orientation on marketing performance is 0.095 . Then the total effect of the path coefficient is $0.206>$ the direct effect path coefficient is 0.095 , which indicates competitive advantage mediate market orientation on marketing performance; therefore, hypothesis 4 is accepted.

\section{The Influence of Entrepreneurial Orientation on Marketing Performance through Competitive Advantage}

The total effect of the path coefficient by adding up the direct effect (point a) and the indirect effect (point b), $0.125+(0.235 \times 0.656)=0.279$.

The result show path coefficient total effect is 0.279 , while the direct influence of entrepreneurial orientation on marketing performance is 0.125 . Then the total effect of the path coefficient is 0.279 $>$ the path coefficient of direct influence is 0.125 , which indicates competitive advantage mediate entrepreneurial orientation on marketing performance; therefore, hypothesis 5 is accepted.

\section{Discussion}

The Influence of Market Orientation on Marketing Performance

The study result shows market orientation influences market performance. The result is in line with previous research, which states that market orientation has a positive and significant effect on marketing performance. Better SME understanding 
Jurnal Bisnis dan Manajemen, Volume 22, No. 2, September 2022, p. 147-161

of market needs and demands is crucial in market orientation, which affects marketing performance (Nurlaely, 2019). Market orientation has a positive and significant effect on marketing performance (Iyer et al., 2019). Market orientation represents understanding customer need and demand and competitor-oriented; coordinating with favorable interfaces will positively influence the marketing performance of MSME (Fernandes et al., 2020).

Market orientation raises innovation development in MSME, which increases marketing performance. Market orientation attempt to adjust to consumer need and want (Riswanto et al., 2020). Market orientation provides an opportunity for MSME to enhance the business that appeals to the consumer. Previous research reinforces that market orientation has implications for marketing performance. Findings (Nurcholis, 2020) state that agility proves as the mediator between market orientation and marketing performance. Other research confirms that there is an implication of market orientation on marketing performance. (Nurlaely et al., 2019) shows that SMEs market orientation is capable of influencing marketing performance through competitive advantage. Research (Frösén et al., 2016) confirms a positive influence between market orientation and marketing performance; its combination encourages steady business development. MSME market orientation establishes marketing performance and has implications for competitive advantage. Market orientation emphasises that consumer needs and wants are an essential part of the marketing process, leading to an MSME competitive advantage (Gotteland et al., 2020; Najafi-Tavani et al., 2016).

\section{The Influence of Entrepreneurial Orientation on Marketing Performance}

The research found entrepreneurial orientation affects marketing performance in MSMEs' business community. The research reinforces previous studies which found entrepreneurial orientation has a positive and significant effect on marketing performance. Marketing performance related to the product is positively influenced by entrepreneurial orientation (Al Mamun et al., 2017). Marketing performance is closely related to MSMEs product number of sales. Marketing performance has an important role in business continuity. This research proves that marketing performance is influenced by entrepreneurial orientation; therefore, sales success is determined by the extent to which MSMEs can identify and have the ability to become entrepreneurs. Entrepreneurial orientation continuously develops; hence, it encourages the creation of better marketing performance in the future. Entrepreneurial orientation indicates MSME innovative, proactive and endeavor take risks to positively influence the marketing performance of the MSME business community (Singh et al., 2021).

Based on research, entrepreneurial orientation strengthens marketing performance in a company (Heng \& Afifah, 2020). Previous research shows a similar result; entrepreneurial 
Jurnal Bisnis dan Manajemen, Volume 22, No. 2, September 2022, p. 147-161

orientation influences marketing performance through an entrepreneurial network and innovation capability (Setyawati et al., 2020). The study indicates entrepreneurial orientation affects marketing performance, which requires an entrepreneurial network as a business catalyst - the MSME decision in business impacts marketing performance (Adekiya \& Ibrahim, 2016; Vuceljz et al., 2011), which aims to business efficiency and effectiveness. Entrepreneurial orientation reflects MSME decision to determine efficiency level to ensure concordance between plan and implementation to achieve marketing objectives (Bernoster et al., 2020; Botha \& Prawlall, 2017; Zanella et al., 2019). Previous research indicates entrepreneurial orientation affects better marketing performance (Covin \& Wales, 2019; Crick et al., 2021; Manzano-García \& Ayala-Calvo, 2020).

\section{The Influence of Competitive Advantage on Marketing Performance}

The study found competitive advantage affects marketing performance in the SME business community. The research reinforces previous studies that discover competitive advantage positively influences marketing performance. Competitive advantages are represented by affectionate responses to customers, an attempt to differentiate from competitors, and superior product quality will positively influence the marketing performance (Winarso et al., 2020). Competitive advantage is an important aspect of the business process. Competitive advantage is a differentiator from other competitors. When a competitive advantage can be achieved, it can stimulate business processes efficiently and effectively. The competitive advantage certainly requires a continuous effort to improve every aspect of the business to produce an advantage in services and products received to consumers.

MSMEs competitive advantage leads to control of the market share (Agarwal et al., 2012). Competitive advantage create product acceptance opportunity in the market, which impacts marketing performance (Girniene, 2013). Marketing performance establishes through product quality and sales intensification over competitive advantages when compared to competitors (Nurlaely et al., 2019; Rachapaettayakom et al., 2020). Competitive advantage leads to changes in the ability of competitors to market a product. Competitive advantage has a positive and significant impact on marketing performance because of its product's ability to fulfill consumer needs and wants (Winarso et al., 2020). The consumer will easily accept MSME products. Competitive advantage has an essential role in creating attractive marketing performance. Previous research strengthens the study results, which shows that the competitive advantage of an MSME can have positive implications for marketing performance (Najafi-Tavani et al., 2016; Parmar \& Mulla, 2015). Marketing performance is developed through a competitive advantage for businesses in promoting their products (Nurhasanah \& Murwatiningsih, 2018). 
Jurnal Bisnis dan Manajemen, Volume 22, No. 2, September 2022, p. 147-161

The Influence of Market Orientation on Marketing Performance through Competitive Advantage

The study result shows competitive advantage has a significant role. It means that the higher the market orientation towards competitive advantage, the higher the marketing performance. Conversely, the lower the market orientation towards competitive advantage impact on lower the marketing performance. Market orientation has a positive and significant effect on marketing performance through competitive advantage (Yasa et al., 2020). This study proves that competitive advantage can mediate the influence of market orientation on marketing performance. The results of this study prove that the ability of SMEs to create competitive advantage can encourage the creation of better marketing performance. Ability to innovate and become a market leader in creating products that consumers need. This effort is a form of creating a competitive advantage in business processes that can be implemented in MSMEs. This study shows that it strengthens previous research, which proves that there is an influence of competitive advantage on performance. marketing and mediate the influence of market orientation on marketing performance

When MSMEs become customer-oriented, competitor-oriented, and coordinating with functions can continuously increase superior value for MSMEs. MSME accomplishes competitive advantage through satisfying customer desires and can communicate effectively between all organizational functions that pay attention to customers and competitors (Meilani, 2018). In addition, to improve their marketing performance, MSME marketers should create competitive advantages in their businesses such as superior in responding to customers in the market, differentiation, and valuable product quality. The MSME effort is indirectly affecting market orientation towards increasing marketing performance in the MSMEs business community.

The study proves that competitive advantage mediates the effect of market orientation on marketing performance. Research result is supported by previous research showing that when an MSME has a competitive advantage, the products are accepted in the market (Nurcholis, 2020). Competitive advantage and market ease are influenced by market orientation to ensure that the products MSMEs sell appropriately with consumer desire (Nuryakin, 2018; Uribe-Echeberria et al., 2019). If the product is appropriate with market orientation and has a competitive advantage, it will optimise marketing performance. Competitive advantage create MSME product readily accepted in the market (Nurhasanah \& Murwatiningsih, 2018). Market orientation has a role in creating competitive advantage and marketing performance (Tan \& Sousa, 2015).

\section{The Influence of Entrepreneurial Orientation on Marketing Performance through Competitive Advantage}

The study found entrepreneurial orientation affects marketing performance through competitive advantage. The result is based on the total indirect 
Jurnal Bisnis dan Manajemen, Volume 22, No. 2, September 2022, p. 147-161

effect of entrepreneurial orientation on marketing performance through competitive advantage. MSME business community can apply entrepreneurial orientation through innovative, proactive, and dare to take risks. Competitive advantage is useful to produce new products or services, seize opportunities, and lead the market. In addition, to improve their marketing performance, SMEs have to create competitive advantages in their businesses. Being superior in responding to customers in the market, differentiation, and reliable product quality will indirectly affect increasing marketing performance in MSMEs' business community (Vuceljz et al., 2011).

Entrepreneurial orientation is related to MSME strategic decisions regarding innovation and efficiency in production (Manzano-García \& Ayala-Calvo, 2020). The competitive advantage created in MSME decision-making encourages a competitive advantage (Jin et al., 2018). The competitive advantage can create an effective marketing process and has implications for better marketing performance. The point of increasing competitive advantage will lead to more superior marketing performance (Setyawati et al., 2020). The marketing process is implemented with certain strategies and following the conditions of MSMEs. The marketing process has implications for improving marketing and sales performance.

\section{CONCLUSION}

Competitive advantage plays an essential role in creating marketing performance. Competitive advantage can mediate several variables; there are market orientation and entrepreneurial orientation. The study results indicate market orientation directly or through competitive advantage affects marketing performance. Market orientation is an MSME understanding of the market combined with a competitive advantage with positive marketing performance implications. Entrepreneurial orientation is an eagerness to understand the market through analysis.

\section{Suggestions}

The marketers of MSME's business community are expected to improve market orientation by implementing a competitor orientation such as responding quickly to competitors' actions to not switch to competitors and observe competitors' strategies in marketing products. Efforts that can be made include establishing relationships with competitors to exchange knowledge and experiences.

In addition, MSME is expected to be more proactive in increasing responsiveness to market opportunities. Besides, taking a competitive advantage to compete with competitors and immediately finding solutions to solve problems in MSMEs so that the marketers of the business community can improve their marketing performance. 
Jurnal Bisnis dan Manajemen, Volume 22, No. 2, September 2022, p. 147-161

Further research needs to investigate and examine these variables in other various sectors, such as food and beverages and services, to compare the result. Comparison of results is still open for any discussion and examinations. Therefore, further research is needed. Further research for MSME export oriented is also need a lot of investigation so that it can provide clearer views of the variables relationships in the various sectors.

\section{REFERENCES}

Adekiya, A. A., \& Ibrahim, F. (2016). Entrepreneurship intention among students. The antecedent role of culture and entrepreneurship training and development. International Journal of Management Education.

https://doi.org/10.1016/j.ijme.2016.03.001

Agarwal, R., Grassl, W., \& Pahl, J. (2012). MetaSWOT: Introducing a new strategic planning tool. Journal of Business Strategy. https://doi.org/10.1108/02756661211206708

Al Mamun, A., Kumar, N., Ibrahim, M. D., \& Bin Yusoff, M. N. H. (2017). Validating the measurement of entrepreneurial orientation. Economics and Sociology. https://doi.org/10.14254/2071-

789X.2017/10-4/5

Bernoster, I., Mukerjee, J., \& Thurik, R. (2020). The role of affect in entrepreneurial orientation. Small Business Economics. https://doi.org/10.1007/s11187-018-0116-3

Botha, M., \& Prawlall, T. (2017). Investigating the effect of location, specifically shopping centres, on franchisees' entrepreneurial orientation: A cluster analysis. South African Journal of Business Management, 48(3). https://doi.org/10.4102/sajbm.v48i3.32
Covin, J. G., \& Wales, W. J. (2019). Crafting HighImpact Entrepreneurial Orientation Research: Some Suggested Guidelines. In Entrepreneurship: Theory and Practice. https://doi.org/10.1177/1042258718773181

Covin, J. G., \& Wales, W. J. (2019). Crafting HighImpact Entrepreneurial Orientation Research: Some Suggested Guidelines. In Entrepreneurship: Theory and Practice. https://doi.org/10.1177/1042258718773181

Crick, J. M., Karami, M., \& Crick, D. (2021). The impact of the interaction between an entrepreneurial marketing orientation and coopetition on business performance. International Journal of Entrepreneurial Behaviour and Research, 27(6). https://doi.org/10.1108/IJEBR-12-20200871

Cuevas-Vargas, H., Estrada, S., \& Larios-Gómez, E. (2016). The Effects of ICTs As Innovation Facilitators for a Greater Business Performance. Evidence from Mexico. Procedia Computer Science. https://doi.org/10.1016/j.procs.2016.07.040

Fernandes, C. I. M. A. S., Ferreira, J. J. M., Lobo, C. A., \& Raposo, M. (2020). The impact of market orientation on the internationalisation of SMEs. Review of International Business and Strategy. https://doi.org/10.1108/RIBS09-2019-0120

Frösén, J., Luoma, J., Jaakkola, M., Tikkanen, H., \& Aspara, J. (2016). What counts versus what can be counted: The complex interplay of market orientation and marketing performance measurement. Journal of Marketing, $\quad$ 80(3). https://doi.org/10.1509/jm.15.0153

Girish, G. P., Joseph, D., Roy, S., \& Amar Raju, G. (2015). Factors influencing adoption of knowledge management systems in India from a micro, small and medium enterprise's perspective. International Review of Management and Marketing. 
Jurnal Bisnis dan Manajemen, Volume 22, No. 2, September 2022, p. 147-161

Girniene, I. (2013). Knowledge management influence on innovation: Theoretical analysis of organizational factors. Proceedings of the European Conference on Knowledge Management, ECKM.

Gotteland, D., Shock, J., \& Sarin, S. (2020). Strategic orientations, marketing proactivity and firm market performance. Industrial Marketing Management, 91. https://doi.org/10.1016/j.indmarman.2020.0 3.012

Hacioglu, G., \& Gök, O. (2013). Marketing performance measurement: marketing metrics in Turkish firms. Journal of Business Economics and Management. https://doi.org/10.3846/16111699.2012.7291 56

Hair, J. F., Black, W. C., Babin, B. J., \& Anderson, R. E. (2014). Multivariate Data Analysis Seventh Edition. In Pearson New International. https://doi.org/10.1007/978-3319-01517-0_3

Heng, L., \& Afifah, N. (2020). Entrepreneurial Orientation for Enhancement of Marketing Performance. International Review of Management and Marketing, 10(3). https://doi.org/10.32479/irmm.9670

Heng, L., Ferdinand, A. T., Afifah, N., \& Ramadania, R. (2020). Service innovation capability for enhancing marketing performance: An SDL perspectives. Business: Theory and Practice. https://doi.org/10.3846/btp.2020.12163

Iyer, P., Davari, A., Zolfagharian, M., \& Paswan, A. (2019). Market orientation, positioning strategy and brand performance. Industrial Marketing Management. https://doi.org/10.1016/j.indmarman.2018.1 1.004

Jin, B., Jung, S., \& Jeong, S. W. (2018). Dimensional effects of Korean SME's entrepreneurial orientation on internationalization and performance: the mediating role of marketing capability. International Entrepreneurship and Management Journal, 14(1). https://doi.org/10.1007/s11365-017-0457-4

Liang, X., \& Gao, Y. (2020). Marketing performance measurement systems and firm performance: Are marketing capabilities the missing links? European Journal of Marketing. https://doi.org/10.1108/EJM-052018-0302

Manambing, A., Mandey, S., \& Tielung, M. V. (2018). Analisis pengaruh orientasi pasar dan keunggulan bersaing terhadap kinerja pemasaran (Studi kasus UMKM kuliner tinutuan di Manado). Jurnal EMBA: Jurnal Riset Ekonomi, Manajemen, Bisnis dan Akuntansi, 6(4).

Manzano-García, G., \& Ayala-Calvo, J. C. (2020). Entrepreneurial orientation: Its relationship with the entrepreneur's subjective success in SMEs. Sustainability (Switzerland). https://doi.org/10.3390/su12114547

Manzano-García, G., \& Ayala-Calvo, J. C. (2020). Entrepreneurial orientation: Its relationship with the entrepreneur's subjective success in SMEs. Sustainability (Switzerland). https://doi.org/10.3390/su12114547

Marolt, M., Zimmermann, H. D., \& Pucihar, A. (2020). Enhancing marketing performance through enterprise-initiated customer engagement. Sustainability (Switzerland). https://doi.org/10.3390/su12093931

Meilani, A. (2018). The Variables and Dimensions of Entrepreneurial Orientation Perceived by Lecturers of Higher Education Institutions. Review of Integrative Business and Economics Research.

Najafi-Tavani, S., Sharifi, H., \& Najafi-Tavani, Z. (2016). Market orientation, marketing capability, and new product performance: The moderating role of absorptive capacity. Journal of Business Research, 69(11). 
Jurnal Bisnis dan Manajemen, Volume 22, No. 2, September 2022, p. 147-161

https://doi.org/10.1016/j.jbusres.2016.04.08 0

Nurcholis, L. (2020). The mediating effect of agility at relationship between market orientation and marketing performance. Jurnal Manajemen Dan Pemasaran Jasa, 13(1).

https://doi.org/10.25105/jmpj.v13i1.5835

Nurhasanah, N., \& Murwatiningsih, M. (2018). The Influence of Market Orientation, Learning Orientation, Innovation and Competitive Advantage to Improve Marketing Performance. Management Analysis Journal, 7(4). https://doi.org/10.15294/maj.v7i4.25637

Nurlaely, Sularso, A., \& Panjaitan, H. (2019). Influence of Customer Relationship Management and Product Innovation on Market Orientation, Competitive Advantage in Improving the Marketing Performance of Food Industry Small Businesses In East Java. International Journal of Business and Management Invention, 8(4).

Nuryakin. (2018). Competitive advantage and product innovation: Key success of Batik SMEs marketing performance in Indonesia. Academy of Strategic Management Journal, 17(2).

Parmar, P., \& Mulla, Z. (2015). Impact of Empowering Leadership and Trust on Attitude towards Technology Adoption. Nmims Management Review, 27, 24-44.

Pizarro, N. (2016). An Integrated Model of Employee Adoption. New England Journal of Entrepreneurship, 19(1), 54-69. https://doi.org/10.1108/neje-19-01-2016b004

Propheto, A., Kartini, D., Sucherly, \& Oesman, Y. M. (2020). Marketing performance as implication of brand image mediated by trust. Management Science Letters. https://doi.org/10.5267/j.msl.2019.10.023
Rachapaettayakom, P., Wiriyapinit, M., Cooharojananone, N., Tanthanongsakkun, S., \& Charoenruk, N. (2020). The need for financial knowledge acquisition tools and technology by small business entrepreneurs. Journal of Innovation and Entrepreneurship, 9(1). https://doi.org/10.1186/s13731-02000136-2

Reimann, C., Carvalho, F., \& Duarte, M. (2021). The influence of dynamic and adaptive marketing capabilities on the performance of portuguese smes in the $\mathrm{b} 2 \mathrm{~b}$ international market. Sustainability (Switzerland). https://doi.org/10.3390/su13020579

Riswanto, A., Rasto, Hendrayati, H., Saparudin, M., Abidin, A. Z., \& Eka, A. P. B. (2020). The role of innovativeness-based market orientation on marketing performance of small and medium-sized enterprises in a developing country. Management Science Letters, 10(9). https://doi.org/10.5267/j.msl.2020.2.019

Setyawati, H. A., Suroso, A., \& Adi, P. H. (2020). Examining the impact of entrepreneurial orientation on marketing performance: the mediating role of entrepreneurial networking and innovation capability. International Journal of Scientific and Technology Research, 9(2).

Singh, S. H., Bhowmick, B., Eesley, D., \& Sindhav, B. (2021). Grassroots innovation and entrepreneurial success: Is entrepreneurial orientation a missing link? Technological Forecasting and Social Change. https://doi.org/10.1016/j.techfore.2019.02.0 02

Tan, Q., \& Sousa, C. M. P. (2015). Leveraging marketing capabilities into competitive advantage and export performance. International Marketing Review, 32(1). https://doi.org/10.1108/IMR-12-2013-0279 
Jurnal Bisnis dan Manajemen, Volume 22, No. 2, September 2022, p. 147-161

Uribe-Echeberria, R., Igartua, J. I., \& Lizarralde, R. (2019). Implementing open innovation in research and technology organisations: Approaches and impact. Journal of Open Innovation: Technology, Market, and Complexity, 5(4). https://doi.org/10.3390/joitmc5040091

Vuceljz, A., Jergovic, A., Petrovic, Z., \& Inic, B. (2011). Entrepreneurship in Serbia, situation and perspective. Technics Technologies Education Management.

Vuceljz, A., Jergovic, A., Petrovic, Z., \& Inic, B. (2011). Entrepreneurship in Serbia, situation and perspective. Technics Technologies Education Management.

Wach, K., Glodowska, A., \& Maciejewski, M. (2018). Entrepreneurial orientation, knowledge utilization and internationalization of firms. Sustainability (Switzerland).

https://doi.org/10.3390/su10124711

Winarso, W., Hady, H., Panday, R., \& Untari, D. T. (2020). Competitive Advantage and Marketing Performance on SMEs: Market Orientation and Innovation of Local Product in Bekasi, Indonesian. Engineering \& Management.

Winarso, W., Hady, H., Panday, R., \& Untari, D. T. (2020). Competitive Advantage and Marketing Performance on SMEs: Market Orientation and Innovation of Local Product in Bekasi, Indonesian. Engineering \& Management.

Yasa, N. N. K., Ketut Giantari, I. G. A., Setini, M., \& Rahmayanti, P. L. D. (2020). The role of competitive advantage in mediating the effect of promotional strategy on marketing performance. Management Science Letters. https://doi.org/10.5267/j.msl.2020.4.024

Zanella, G., Castro Solano, D. B., Hallam, C. R. A., \& Guda, T. (2019). The role of the organization in the entrepreneur-opportunity nexus. International Journal of
Entrepreneurial Behaviour and Research. https://doi.org/10.1108/IJEBR-03-20180169 